\title{
Political Training and Social Change in the 1960s and 1970s: The Educational Activities of the Latin American Central of Workers (CLAT)
}

\author{
Gabriela Scodeller \\ Universidad de Buenos Aires
}

\begin{abstract}
This article reconstructs the educational policies of the Latin American Confederation of Christian Trade Unions (CLASC) - the name of which was later changed to the Latin American Central of Workers (CLAT) -in the context of the Latin American Cold War. It provides an empirical description of its pedagogical praxis, showing how it was shaped in constant dialogue with the region's conflictive context. It explores how they viewed political training in relation to both their organizing efforts and struggles, applying a conception that brought together "action, organization and training" as integrated elements, in the run to foster class awareness, build up a "new society," and “workers' organized power".
\end{abstract}

During the Cold War, education became a strategic issue, and in Latin America, especially after the Cuban Revolution, several labor and intergovernmental international organizations devoted a great deal of attention to the problem of educating workers. Despite its importance at the time, however, workers' education has rarely been studied by labor historians. There is little information about the education of workers in the broad and extensive literature on international labor movements and organizations, even where data and archival material are available. ${ }^{1}$ This article will focus on the educational policies and programs of one international organization of religious inspiration in the Americas, the Latin American Confederation of Christian Trade Unions (CLASC), founded in Chile in 1954 and renamed the Latin American Central of Workers (CLAT) in 1971. During the 1960s and 1970s the organization was swept up in the process of political radicalization that many religious groups experienced. Initially a federation of Christian trade unions, it refashioned itself as a grassroots "movement of workers" determined to create a new society. We know a little about the organization itself, but almost nothing about its educational programs, a deficiency that this essay is intended to repair. ${ }^{2}$

Given the state of the field, this effort is necessarily exploratory. It attempts simply to describe CLASC's and especially CLAT's educational activities so that we might better understand what they did and how they did it. This article is especially concerned with the organization's practices of reflection and its programs of action, specifically the relationship between its political education programs and its trade unionism, its theory and its practice, in a highly conflictual context. As we shall see, when the leaders of CLASC decided to 
refashion their federation into a mass membership movement organization, they also launched an ambitious educational program aimed at both the membership and the leadership in order to build support for their new agenda. The case of CLASC/CLAT is particularly interesting because the members of the organization were intimately involved in political struggles in their own countries, where they sought to bring organization, education, and action together as integral parts of a pedagogical and political practice. In the pages that follow we will explore these issues, using internal organizational documents and correspondence, as well as the books, pamphlets, and periodicals published by the organization that are available in several archives. ${ }^{3}$

Before looking at CLASC/CLAT more closely, however, it will be helpful to review briefly other organizations and agencies active in the same area during this period. In the wake of Khrushchev's 1956 denunciation of Stalin and the Soviet invasion of Hungary, which occurred a few months later, the Communist-dominated World Federation of Trade Unions (WFTU) lost much of its standing in many Latin American countries. ${ }^{4}$ Unions affiliated with the Inter-American Regional Organization of Workers (ORIT), a branch of the social democratic International Confederation of Free Trade Unions (ICFTU), tried to step into the breach, offering its own programs and inducements in an attempt to expand its influence in the region. ${ }^{5}$ The International Labor Organization (ILO) also became a more active presence. ${ }^{6}$

Each of these groups undertook significant Latin American workers' education initiatives. In 1960 the ILO established its influential International Institute for Labor Studies (IILS) in Geneva and strengthened its Workers Education Division, which provided support for workers' education efforts around the world, concentrating on labor rights and on professional development courses for trade unionists. ${ }^{7}$ In 1962, ORIT launched its Inter-American Institute for Labor Studies (IIES) and the US-based AFL-CIO opened its American Institute for Free Labor Development (AIFLD). At first, these programs were highly political and ideological, but they, too, increasingly focused on technical and professional training. ${ }^{8}$ Finally, CLASC began opening different Institutes for Social Studies (IES) in 1963. In contrast to the ILO and ORIT, however, CLASC became more rather than less ideologically oriented as the years went by, and in the 1970s it launched a comprehensive, mass-based education program directly concerned with fundamental sociopolitical and economic matters - a shift in priorities signified by its 1971 name change.

ILO and ORIT's educational strategies can be understood within the frame of capitalist social relations. But while the ILO focused on the protection of individual labor rights in order to guarantee better labor power-selling conditions, ORIT sought to strengthen trade union structures and to constitute an organized and mostly disciplined labor movement. CLASC/CLAT, in contrast, pursued a more radical agenda. It proposed to do away with the capital-labor relationship itself. This ambition matched its belief about the central role that worker organizations, such as trade unions and cooperatives, should play in society as well as their beliefs about the kind of education and leadership 
development necessary for them to do so. The other groups had different views. The ILO in effect sought to promote the spread of more harmonious employment relations based on the participation and enhanced bargaining power of "responsible" union leaders, while ORIT sought to foster widespread economic development and social integration by "modernizing" the trade unions and their leaders. It wanted them both to be part of "socioeconomic planning" on a more equal footing with government officials and the employers. For its part, CLASC/ CLAT dismissed these approaches as too conciliatory and called for the "movement of workers" to develop a "critical consciousness" in order to win "liberation" and build a new society on the basis of "workers' organized power." As we will see, these goals had direct implications for CLASC/CLAT's educational policies and programs.

\section{CLASC/CLAT in its Context}

The International Federation of Christian Trade Unions (IFCTU) chartered CLASC in 1954 in Santiago, Chile, as part of a strategy to boost Christian unionism in the region. The name change in 1971 reflected the organization's effort to broaden its membership. ${ }^{10}$ It was no longer restricted only to unionized Christian workers. Henceforth, the organization was also to encompass the urban poor, peasants, women, young workers, and members of the cooperative movement. ${ }^{11}$ Instead of being a federation of unions, it was to be a "Movement of Workers." According to Emilio Máspero, CLAT's secretary general, the organization sought to overcome

primitive "workerist" concept[s] and certain unilateral and incomplete Marxist definitions, unsuitable to interpret the typical and original situation of the working class in Latin America. For us, a worker is any person whose economic, legal, social, cultural, technical and psychological situation is linked to a subordinated and dependent professional activity. And also anyone whose means of subsistence is his labor force-manual or intellectual-alienated and appropriated at the service of capital. ${ }^{12}$

Precise data are not available, but CLASC membership for the years 1967-1968 has been estimated at between five hundred thousand and one million members and sympathizers. ${ }^{13}$ Although it had representation in most Latin American countries, its main influence was among peasants and urban poor sectors of less developed countries. Thus, its strength lay in Venezuela, Ecuador, Chile, Dominican Republic, Colombia, and other minor Caribbean states. It was for a time the second largest labor organization in Latin America and, in more global terms, the most important labor movement of Christian orientation. ${ }^{14}$

While founded by the IFCTU, CLASC followed its own path and operated independently of the various institutions with which it has been often uncritically identified, including the Catholic Church, Christian democratic parties, and the IFCTU. It is best understood in the context of the radicalization that 
diverse Latin American religious groups experienced during the 1960s and 1970 s, itself a symptom of the accelerated pace of both urbanization and secularization in this period. Although CLASC never abandoned its Christian social philosophy nor its inspiring principles devoted to a holistic understanding of humanity and society, the more moderate, confessional tone of CLASC's initial congresses resolutions slowly changed. The third CLASC congress, held in 1959 in Ecuador, identified capitalism as the cause of poverty, to overcome which, the congress concluded, would require a political and not just a confessional struggle.

Nevertheless, the solutions sketched were still within the framework of Catholic social teachings. In contrast, the fifth CLASC congress held in Panamá in 1966, which came to be known as the "new dimensions" congress, openly exposed the organization's revolutionary tendencies. After this meeting, CLASC reoriented its work, transferred its headquarters to Venezuela, and appointed Emilio Máspero secretary general. ${ }^{15}$ The sixth congress in 1971 subsequently ratified these "new dimensions" by changing the organization's name to CLAT and clarified its political perspective and direction. ${ }^{16}$ CLAT's goals were no longer to be defined in terms of "solidary development" but rather "liberation," in the struggle for which rank-and-file workers were to play a key role. ${ }^{17}$ In keeping with this shift, CLAT's main concern was to "build up workers' organized power.",

There is a scholarly consensus that Latin America's Cold War started as soon as World War Two ended, although it took another turn after the Cuban Revolution of $1959 .{ }^{19}$ US policy to stop the spread of communism in the region took different forms: the deployment of counterinsurgency measures; support for military coups; other territorial and political interventions in different parts of the continent; and finally, the more reformist approach that informed the Alliance for Progress Program (1961). ${ }^{20}$ Such actions were motivated by the conviction that vital US interests were at stake. In fact, from rural and urban guerrillas to nationalist or leftist governments, a marked antiimperialist and anti-US feeling flourished throughout Latin America. From the early 1970s on, labor unrest not only increased in many countries, but also took a political turn to the left, resulting in the radicalization of student, religious, cultural, and academic groups, which collectively formed what came to be known as the "New Left." 21

CLASC/CLAT belonged squarely within the New Left. It viewed the primary axis of confrontation as North-South rather than East-West and thought the argument over "capitalism or communism" an "imperialist dilemma." 22 Its members generally held strong antiimperialist positions and embraced "Third Worldism," which to them meant promoting the creation of the great Latin American homeland. ${ }^{23}$ Along the same lines, CLASC/CLAC members emphasized the idea that, until recently, Latin American trade unionism had been more an imported product than the indigenous result of its own workers' creativity and experiences. They meant to change all that. The organization's political hopes envisioned the democratization "of power, of possession and of knowledge," to be effected by socializing the means of decision, 
production, and circulation as well as culture, science, and technology. This "real and integral democracy" was described as "communitarian socialism," which rested on true self-government, understood in social, economic, and political terms, and which was believed to promote the growth of new forms of social relationships based on solidarity and equality. ${ }^{24}$ To effect these changes, the leaders of CLASC/CLAT argued, a "real cultural revolution has to occur within the labor movement, which will liberate us once and for all from magical and naïve thinking, and produce in all workers and in all their leaders a profound and lucid critical and political awareness." 25

\section{Education for "Cultural Revolution"}

CLASC/CLAT developed an elaborate educational program to foster the awareness and critical thinking that its plans for a far-reaching cultural revolution demanded. From 1966 to1974 the organization's Latin American Institute of Social Studies (ILATES), directed by José de Jesús Plana, served as its educational headquarters, after which it was replaced by a new Latin American Workers' University (UTAL). ${ }^{26}$ Linked to this central hub were both regional and specialized institutes, as well as numerous national centers that were responsible for education of the rank and file. ${ }^{27}$ ILATES and later UTAL provided technical assistance to these centers and to the educational departments and staffs of its affiliated organizations. They also conducted seminars for union leaders at its headquarters. After the UTAL opened, its staff also conducted research, documentation, and communication projects. ${ }^{28}$

During its first fifteen years, CLASC held more than two hundred seminars and courses at ILATES and more than five thousand educational events at its regional and specialized centers in different countries. ${ }^{29}$ Between 1965 and 1967, about thirty-five thousand workers, activists, and leaders attended CLASC courses, while in the next year alone they attracted some thirty thousand participants. ${ }^{30}$ Between 1966 and 1972 ILATES also organized forty-one more intensive residential courses, and another 133 were held between 1974 and 1983, once UTAL became fully active. ${ }^{31}$ Overall, 1,150 officials of different levels attended the residential courses organized by ILATES. More than ninety-two percent of these participants were men. Just more than half of them had completed a secondary education, and eighty percent were twenty and forty years old. Almost the same percentage (eighty-two percent) came from urban areas. Finally, in geographical terms, almost half were from the Andean region, about one-quarter were from Central America (23.5 percent), another one-eighth of the attendees came from the Southern Cone (thirteen percent), and a similar number from the Caribbean (twelve percent). ${ }^{32}$

The courses themselves were organized both for particular groups or by region (in order to serve all those who performed similar tasks in different affiliates). Special programs were also specifically designed for women and young members. In addition to specialized topics, more general subjects were also addressed, such as socioeconomic systems and doctrines, the Christian concept of 
labor and trade unions, the nationalization of industry, agrarian reform, trade unionism (its history, aims, and organizations), political economy and development, collective agreements and bargaining techniques, labor relations and legal procedures, and others. ${ }^{33}$

Different types of events were also designed to complement one another. An initial course would consist wholly of lectures with discussion. It would be followed by a seminar in which participants worked in small teams to analyze and develop a presentation on the issues being considered. The seminars would then be followed by a plenary session in which each group would present their conclusion for discussion by the whole. Furthermore, even before the formal course of study began, future participants were required to do some preparatory work based on a set of materials (documents, reports, guides, and questionnaires) sent to them by the organizers.

CLASC/CLAT dedicated approximately seventy percent of its resources to training its leaders, activists, and members. ${ }^{34}$ Funding came from both international solidarity and aid organizations, as well as member donations and fees (participants paid a tuition rate equal to one day's pay). ${ }^{35}$ The organization also created different solidarity funds so that those institutes with a more secure revenue stream could contribute to the support of those with less. After the creation of UTAL, the cost per participant averaged about two thousand dollars. ${ }^{36}$ Not surprisingly, therefore, "external solidarity support" accounted for seventy-five percent of the CLASC/CLAT's education budget in 1971, ninety-six percent in 1975 and eighty-eight percent in $1978 .{ }^{37}$

\section{Educating the Educators}

Among the numerous courses offered by CLASC/CLAT, some were specifically designed for the educational officers and staff of affiliated organizations. The first of these programs, known as the Latin-American Seminar for Educators, was held in Caracas in 1965 and took place annually from then on. The course materials prepared for these seminars provide a clear picture of their organizers' intent and perspective. The 1971 CLASC/CLAT handbook for the training of educators, to take one example, was divided in two parts. The first part offered reflections on the special character of adult education and the distinctive needs of adult learners. The second part then proposed an "ideal system of education," based on the experiences of the book's authors with various activities in multiple venues during the preceding years. ${ }^{38}$ Each section had important implications for how education programs were best organized and conducted. In the first part, the authors contrasted the "traditional concept" of education, in which teachers were placed on a different, higher plane from their students, with the more "dynamic, progressive and permanent process" of adult learning. Learning in the first case was passive; in the second case, it was active. Adults, they argued, had their own well-developed ideas about life and learning, which they had acquired from reflecting upon their own experiences. They also learned best and most easily from themselves and from those 
around them. The aspiring worker educators were therefore encouraged to be "animators" more than traditional teachers.

The goal of a course was to assist students to become better able to receive, distinguish, capture, understand, retain, create, and communicate information and knowledge. The last two-thirds of the 1971 handbook was therefore devoted to the technical and practical aspects of designing and carrying out such a purpose. A "pedagogy of transformation," the authors argued, required participatory methods, in which the worker "as subject becomes a dynamic agent who individually and in collaboration with others constitute and enable their learning." 39 The handbook then goes into considerable detail about active methods of teaching and learning, as well as the corresponding techniques that such methods required. ${ }^{40}$ Each course was to encourage three kinds of learning: to know (i.e., acquire information and knowledge); to know how to do (i.e., acquire skills and abilities); and to know how to live (i.e., develop appropriate commitments, lifestyles, and values). ${ }^{41}$ A whole chapter was also dedicated to how to organize educational events, which were seen as the most dynamic part of the entire organized educational process. Events were the point at which organizational objectives, programs, animators, participants, and methods met. Finally, the handbook emphasized the importance of following up with participants in order to assess the impact and results of the program. ${ }^{42}$

The most important point of the training was that the courses, seminars, and plenaries were to provide systematic, well-structured encouragement for participants to learn how to take charge of both their own lives and their collective circumstances. Ideally, each part of a program moved systematically from what was simpler, concrete, and well known toward that which was more complex, more general, and unknown. In this way, participants were encouraged to discover the ways of "being, thinking and acting" that were appropriate to the "militant man [or woman]" and summarized as the three pillars of the education process: "information, reflection, action." The overall goal of the training program was to convey that CLASC/CLAC had "a dynamic conception of organization, a dialectical conception of action, and a militant conception of education." $" 43$

At all levels, CLASC/CLAT's approach to workers' education followed the "method of life revision" created in the 1920s by Belgian priest Joseph Cardijn, a founder of the Young Christian Workers (YCW) movement. The values animating the YCW were exemplified by its slogan, "See, Judge, Act." 44 The critical pedagogy of Paulo Freire also influenced the group's educational outlook, although not as emphatically as Cardijn. ${ }^{45}$ The methods of Cardijn and Freire were in any case remarkably similar, which makes it impossible to say what and how much was incorporated from each one. ${ }^{46}$ CLASC/CLAT's educational practice fit the YCW approach closely, especially their common reliance on study circles and participant surveys. ${ }^{47}$ As for Freire, CLASC/CLAC course developers and instructors took from him not so much his methods as his emphasis on the importance of a linkage between the classroom and the students' sociocultural reality. ${ }^{48}$ In CLASC/CLAT's own readings and reappropriations of 
these influences, however, it was the third pedagogical moment, that of action, that was paramount. It would eventually become, to the exclusion of all else, the axis around which the whole educational program would turn.

A political goal thus informed the whole educational program: increasing worker awareness and capacity in order to achieve social transformation. But this larger goal did not prevent CLASC/CLAC organizers and instructors from arguing that because of the technical nature of running a union, the education the organization needed to provided its union affiliates with "a very specialized discipline," focused on technical processes and structures. ${ }^{49}$ As the CLAT instructors saw their responsibilities, their "work [was] A TECHNICAL FUNCTION carried out with MILITANT MEANING." 50 This insistence, however, led to disputes between the trainers and the leadership over the relative autonomy of the former, and the relationship between the educational division and the political leaderships was occasionally tense. The educational staff shared the goals of the organization's leadership and was prepared to take direction from the highest levels, but it warned that sometimes "the contingency of Political Leaderships is not consistent with the more permanent aims of Education." 51

\section{Education from Below}

Political training for the movement's rank and file was a very significant facet of CLASC/CLAT's education program. The organization's affiliates were active in regions and among population sectors where literacy and years of schooling were low. They therefore had to rely on different kinds of media to communicate their message. Political posters, for example, used powerful images to transmit slogans, commemorate meaningful dates in the history of the labor movement, and exhort workers to mobilize and struggle. Songs and ballads, like the "Anthem of Latin-American Workers," which was recorded and sold, were another example, as were films, people's theater, music, and dance festivals. $^{52}$ CLASC/CLAT's most systematic effort at grassroots education, however, was its "Collective Process of Ideological Explication" (PCEI) implemented in 1973. It aimed to create "a real militant and mass unionism, a unionism renovated from its own grassroots" and also to help realize the new society that CLAT had as its ultimate goal. ${ }^{53}$ Believing strongly that the struggle against capitalism and its "alienation" had a cultural front, the PCEI was to "lay the foundations of a new culture of workers, of a clear and solid capacity of autonomous thinking ... for the organized working class to rise as the historical actor of the great processes of popular, national and Latin-American liberation."54

The PCEI was the result of discussions at the organization's sixth Congress in Venezuela, when delegates also rechristened themselves as CLAT. Five working phases were to be undertaken, the conclusion of which was to be the new society, realized at least in embryo and in time for the next Congress, scheduled for 1977. During the first phase, which was to last eight months, education officers were to develop the organizational structures, design the factual and 
didactic materials, and start training the PCEI's "animators" or study circle leaders. After this period of preparation, each successive phase was to accomplish the goals of the four projected remaining phases, each with its own theme: (1) the history of CLAT's efforts to develop an "integral humanism"; (2) an overview of national, Latin American, and world realities; (3) the creation of workers' organized power; and (4) the realization of the germ of a new society. ${ }^{55}$ The whole effort was to be sustained through members' contributions; and since the initial investment was $\$ 10,000$, each participant was asked to donate one dollar. ${ }^{56}$ It was an ambitious program, not unlike the contemporary efforts of those inspired by the era's liberation theology to establish "base Christian communities" in the 1960s. As we will see, these expectations had to be adjusted.

The PCEI was coordinated in a centralized manner by a "Latin American Political Committee" (CPL), although it also was designed to rely upon study circles. $^{57}$ These were groups of no more than ten workers guided by an "animator," who played a key role. Animators not only had the responsibility to ensure the circle's continuity, but also kept the communication open between rank-and-file participants and the leadership. Each animator was to report on the discussions in their circle, upon which a general report would be based afterward. Through this "collective, critical, and creative reflection," workers were expected to contribute "greater depth and precision [to the movement] ... new ideas, new concerns, new perspectives, new formulas, together with the necessary corrections." 58 According to CLAT, a thousand study circles emerged in the entire region. The goal was to double that figure, reaching twenty thousand members by the end of the process. ${ }^{59}$

The preparatory phase of "information and animation" was launched as planned. Its purpose was to create the subjective conditions for participation. The study circles and the national political committees were formed, and the training of the animators began. ${ }^{60}$ But the effort soon encountered some difficulties, especially regarding the consolidation of the circles. In the end, only two more of the stipulated five phases were completed: The first, initially planned for July 1973, started only in November followed by a second in January 1975, which introduced some changes in the process after a preliminary evaluation. ${ }^{61}$ Moreover, as the implementation of the PCEI proceeded, the directorate of UTAL, which was in charge of the implementation, became very critical of its results. Its critique revealed the difficulties that CLAT's training team encountered as it struggled to implement the organization's ambitious education project.

The UTAL report identified two fundamental problems with the PCEI. First, it criticized the national political leadership's commitment to the process, which, in the words of the assessment, was "paralyzing and impeding the development of the Process" with its "immediate activism."62 At the rank-and-file level, the implementation of circles had been very difficult, especially from 1975 onward, when their number dropped considerably and it was not possible to follow up with them. This was particularly true among peasants 
in the rural areas, where even though the PCEI had been launched in almost every one of CLAT's member countries, the organization encountered many difficulties in maintaining the proposed working method. Among the reasons offered for these difficulties were that "there are no animators, people are very indolent, the material is inadequate, etc."63

Secondly, the UTAL report also noted the lack of a good system of open or rank-and-file education, upon which the success of the PCEI depended. ${ }^{64}$ As a result, at the level of leading cadres or education officials some of the anticipated meetings and events had to be postponed or even suspended, including so-called Ideological Seminars, which were designed to support the development of the PCEI. Only two out of three proposed seminars took place, and the second one had to be postponed for a period due to a lack of participants. In addition, the seminars that were held did not build upon the prior work of study circles and thus did not fulfill their main objective, which was to synthesize the study circle discussions and pass the results up to the political committee.

Given grandiose expectations of the effort and the complicated structure put in place to supervise it, we ought not be surprised there were difficulties. Keep in mind that while the contents and methodology to be used by the process were developed by the ILATES/UTAL team, the political orientation rested in the hands of the CPL, and the responsibility of PCEI's effective implementation laid with the national institutes or education departments. ${ }^{65}$ These divisions were expected to guarantee the essential tasks, like the training of the animators or the dialog among the participants, including distribution of booklets and other documents, and the compilation of the study circles' reports.

\section{Education from Above}

After 1975, with UTAL fully functional, the rank-and-file education of the PCEI was supplemented and ultimately replaced by an educational policy more focused on the training of cadres. ${ }^{66}$ UTAL had been set up to "develop higher and integral training ... for the leaders and militants of the Movement of Workers," who were to possess a "critical and global vision" and be "specialists in those fields of knowledge, science and technique related directly or indirectly to the destiny of the working class and its organizations." ${ }^{\text {"67 }}$ The courses or seminars developed to accomplish this goal were known as "Advanced Educational Seminars in Global Political and Strategic Leadership". These courses were intended for leaders of national confederations and federations. They included both more general seminars, which focused on content of interest to the organization as a whole, and more specialized courses (e.g., in economics, administration, social communication, etc.). Each of these types of courses involved a three-month period of intensive, residential study, to which were added a series of "remote and proximate preparatory" steps required of each student. ${ }^{68}$ Between 1974 and 1983, 264 leaders from CLAT's affiliates completed these kinds of advanced courses. ${ }^{69}$ 
After CLAT's seventh congress in 1977, the organization's educational priorities shifted away from the rank-and-file emphasis of the PCEI to focus more and more on leadership training and development. Its so-called "basic and massive training" was not abandoned, but it was relegated to a secondary status. According to the CLAT leadership, the brutality of Latin American dictatorships established in the aftermath of the democratic awakening of the 1960s and 1970s made it necessary to reinforce "the theoretical and political training of cadres." ${ }^{70}$ It also suggested that the organization had grown too rapidly, which had caused sharp internal conflicts. ${ }^{71}$ On the latter point, some of the affiliated educational institutes were accused of not following CLAT's direction and of having moved away from its path. CLAT's secretary general even accused some of the institutes of having been infiltrated, and he demanded that greater vigilance be exercised over the course contents, animators, methodologies, and materials. ${ }^{72}$ The seventh congress proposed to rectify this situation by calling for a "new stage" of the organization's educational work, the primary objective of which was to be the training of cadres at all levels by the already existing structures, but "under strict political and strategic control.",73

Two shifts or changes in policy thus took place at this meeting. First, priority was to be given to the ideological education of leadership cadres. Second, pedagogy, or teaching methods, was deemphasized in favor of explicit politicalintellectual (i.e., ideological) content. According to CLAT, while "methodology is of radical importance," for the workers" movement "the contents [of the lessons] constituted ... the most important [element] of the training process." 74 In other words, content was now explicitly given a priority over form. Active learning was in effect to be replaced by learning action.

Such fluctuations could be seen as inconsistencies. But they also may be read as evidence of a continuing process of self-evaluation in the context of the ongoing struggle and needs of the workers' movement. At the beginning of the 1970s CLASC/CLAT's educational proposal built itself around the triad of "Information, Reflection, Action." But by the end of the decade, the organization regarded the simpler phrase "reflected action" to be a better description of its educational framework and ambitions. Education, CLAT began to argue, "occurs fundamentally through the experience of action and purposeful confrontation, consciously planned." Workers become class conscious when they "take part in a mass, class and combative action, and discover their class position [as workers], and the meaning of unity and class solidarity." 75 Education was no less important in this formulation. But it had been significantly redefined, not only with respect to whom the target students were, but also with respect to the contents taught and the methods and techniques being used. The new and different requirements that the CLAT team felt the political context imposed upon them shifted the emphasis away from learning and toward doing, the effect of which was to link informing and reflecting (or thinking) more closely to acting. Instead of "See, Judge, Act," the new scheme was to be "Act/Organize, Think/Act."76 ILATES/UTAL's desire to educate in order to encourage workers act appears thus to have made them 
downplay CLASC/CLAT's earlier emphasis on the need "to see," or to be informed, and "to judge," or to think, as well as to act, the effect of which was to cause them to lose perspective on their own situation.

Data from affiliates in different countries suggest that the organization had neither the structures nor the staff to implement its ambitious educational agenda, either in qualitative or quantitative terms. For example, from the extensive and probing of self-criticism by working groups in the Third Course Seminar for Educational Supervisors (1967), it is evident that the situation and preparedness of workers' educators was still very problematic. The participants in the course themselves pointed out the scarcity and high turnover of teachers, the inconsistencies between what was being taught and what was being done, as well as the increasing reliance on improvisation and a growing lack of realism, not to speak of deficient funding and the continuing tensions within the leadership, among many other issues. ${ }^{77}$ Eight years later those in charge of the Peasant Training Division also complained that the activities under the Open Training System were almost paralyzed and reported that in no country was there either an adequate structure or sufficient interest on the part of the leadership to fix the problem. ${ }^{78}$

Even among the movement's leading cadre, others noted a lack of intellectual preparation, bad study habits, a poor grasp of CLAT's organizational structure and priorities, and bad marks, which they attributed to physical fatigue, mental exhaustion and bad health conditions, as well as to the lingering resistance, which typically demanded a great deal of participation, personal creativity, collaborative work, and so forth. ${ }^{79}$ A country-by-country survey conducted in 1979 revealed that in some national institutes there were not teams of responsible educators, but only one or two people in charge of educational activities, and many of them had only recently assumed responsibility for the work. The exceptions were Honduras, Colombia, Ecuador, and Argentina. ${ }^{80}$ In short, the reality was incompatible with the quantity and quality of the proposed program and its tasks.

\section{A Theme and Its Variations}

Our intention in this article has been to contribute to $I L W C H$ 's special issue on workers' education by providing an empirical reconstruction of the pedagogical praxis of a relatively unknown, but nevertheless important and creative Latin American labor organization. We have tried to show how the complexity and reach of its educational project was shaped by the extreme political and social conflicts that wracked Latin America in the 1960s and 1970s. We also explored the tensions and dilemmas experienced by the leaders, instructors, and students who participated in its programs. In doing so, we wanted to learn how the leaders and members of CLASC/CLAT viewed political training in relation to both their organizing efforts and their struggles for recognition and development in the larger political economy. 
In the case of CLASC/CLAT, we concluded that education was conceived as a constitutive part of the dynamics of conflict and, as such, was understood to be essential to enhancing not only members' understanding, but also their ability to struggle. CLASC's emphasis on education, action, and organization remained always at the center of their work. But the rapid and radical shifts in the political context of the continent led to changes that emphasized different aspects at different times, depending upon the prevailing circumstances. Interestingly, while education was understood as an essential tool for the workers' movement to use in order to deepen its actions in a thoughtful, class-conscious way, this didn't make them forget the importance of pedagogical aspects. But CLAT's leadership consisted predominantly of political cadres. Although it talked with educational center staff and experts, the organization's leaders relied almost exclusively on themselves to develop and implement the called-for education. The result was that CLAT's educational efforts, which were especially well-advanced in the 1970 s, came increasingly to resemble the rigid party-like training it otherwise denounced.

As we have noted, the constraints imposed by the sociopolitical context on the internal development of the workers' movement and its educational ambitions does explain, at least partially, the importance that came to be attached to the actual content being taught, without any reference to the groups being targeted. We have also noted that the methodological concerns associated with the elaboration, transmission, and recreation of knowledges continued to be a concern. Nonetheless, the relationship between form and content at different times and in different places varied enormously. In CLAT's case, the interest in pedagogy and methodology became less important as time went on. The intensification of social conflict forced the leadership to attempt to speed up its education and training programs. In the heat of battle not as much time could be spent on collective reflection and, as a result, CLAT came to rely more on the classic, top-down "banking" model of education that had once been the target of its criticism.

Finally, it is precisely with regard to the way in which CLAT combined action and reflection that its originality should be emphasized, both compared to its contemporaries and with respect to the traditions that nourished it. CLASC/CLAT had been inspired by Cardijn's approach to Catholic social action and education, which he had developed earlier in the century. CLAT also explicitly and directly incorporated the Freirean emphasis on transformative action as a horizon and a guide for their own radical, noncommunist and anticapitalist educational praxis. The difficulties we have encountered in trying to define this praxis have to do with the fact that the CLASC/CLAT always aspired to achieve a radical transformation of society by means of the collective and active involvement of its members, right here, right now, in the realization of a new sociopolitical model. In other words, the project was in fact always under construction, with no clear or solid ground on which to stand and feel secure. Workers' education continues to be such a field of conflict today, with different traditions, ideologies, and practices interacting, 
confronting, negotiating, and combining with one another. By focusing on the fluctuations, richness, and dilemmas of CLASC/CLAT's educational praxis, we can see how, in one case at least, struggle came to be considered an educational as well as an organizational imperative.

\section{NOTES}

1. For example, Anthony Carew et al., eds., The International Confederation of Free Trade Unions (Bern, 2000); Jasmine Van Daele et al., eds., ILO Histories. Essays on the International Labour Organization and its Impact on the World during the Twentieth Century (Bern, 2010).

2. Efrén Córdova, "El neosindicalismo cristiano en la América Latina: CLASC," Revista de Ciencias Sociales 2 (1968), 255-95; Michael Francis, "Revolutionary Labor in Latin America: the CLASC," Journal of Inter-American Studies 10 (1968): 597-616; Robert Alexander, International Labor Organizations and Organized Labor in Latin America and the Caribbean. A History (Santa Barbara, 2009), 199-227. For a comprehensive institutional history of the organization, see Gerhard Wahlers, Nace una alternativa (Miami, 1991).

3. The edited sources cited here (books, brochures, and periodicals) can be found at the library of the International Institute of Social History-Amsterdam (hereafter IISH); memos, internal documents and specific educational material and booklets correspond to the A. Vanistendael Collection at the Documentation and Research Center on Religion, Culture and Society-Leuven (hereafter KADOC).

4. On its regional organization, the Confederation of Latin American Workers, see Patricio Herrera González, "La Confederación de Trabajadores de América Latina. Una historia por (re)significar (1938-1963)," Secuencia. Revista de historia y ciencias sociales 86 (2013): 193-218.

5. On ORIT see Alexander, International Labor Organizations, 109-172; Magaly Rodríguez García, Liberal Workers of the World, Unite? The ICFTU and the Defense of Labour Liberalism in Europe and Latin America (1949-1969) (Bern, 2010); Robert Walters, Jr., and Geert van Goethem, eds., American Labor's Global Ambassadors. The International History of the AFL-CIO during the Cold War (New York, 2013), 123-214.

6. To follow the ILO trajectory in Latin America, see Fabián Herrera León and Patricio Herrera González, eds., América Latina y la Organización Internacional del Trabajo: redes, cooperación técnica e institucionalidad social, 1919-1950 (Morelia, México, 2013).

7. The fact that it appeared as an institution of "experts" in the field of professional training as well as in pedagogical matters, holders of a scientific "neutral" knowledge, promulgated their proposals to a variety of very diverse groups concerned with workers' education.

8. We have studied elsewhere the educational policies of such organizations, see Gabriela Scodeller, "Latin American 'Free Trade Unionism' and the Cold War-An Analysis Based on Educational Policies," Labor History 57 (2015); Gabriela Scodeller, "Educar en derechos laborales: políticas y acciones desplegadas por la OIT durante los años 1950-1970," in Regular y legislar el mundo obrero latinoamericano. Aportes para una historia regional de la OIT, ed. Laura Caruso and Andrés Stagnaro (La Plata, forthcoming). For AIFLD's activities in the Southern Cone, see Jorge Basurto Romero, "El sindicalismo y la penetración ideológica de los Estados Unidos en América Latina," Revista Mexicana de Sociología 34 (1972): 551-94; Hobart Spalding, "U.S. and Latin American Labor: The Dynamics of Imperialist Control," Latin American Perspectives 3 (1976): 45-69; Pablo Pozzi, "El sindicalismo norteamericano en América Latina y en la Argentina: el AIFLD entre 1961-1976," Revista Herramienta 10 (1990); Alexander, International Labor, 265-88; Walters, Jr., and van Goethem, eds., American Labor's, 201-14 and 177-99.

9. CLASC, Formación de trabajadores para América Latina. Manual de Formación por el grupo responsable de formación de la CLASC (Caracas, 1971), 109, in IISH.

10. In turn, termed as Confederación Latinoamericana Sindical Cristiana since 1966.

11. This is why, according to Córdova, CLASC/CLAT was more a "social movement of proletarian base or of marginal sectors" than a union confederation. Córdova, "El neosindicalismo cristiano," 257. 
12. Allocution was given in 1972 during the First Seminar of Workers of Education, Science and Culture. CLAT, Vocero del movimiento de los trabajadores comprometidos con la liberación de los pueblos de América Latina, Caracas, year VI, no. 44, October 1972, 8, in IISH.

13. According to the Organization, the number increased to five million; see Emilio Máspero, "Latin America's Labor Movement of Christian Democratic Orientation as an Instrument of Social Change," in Religion, Revolution, and Reform: New Forces for Change in Latin America, ed. William D' Antonio and Fredrick Pike (New York, 1964), 180.

14. Alexander, International Labor, 224.

15. He was an Argentine union leader (1927-2000) educated in various Jesuit centers, who joined the Young Christian Workers (YCW) and in 1955 founded the Christian-oriented union federation Acción Sindical Argentina (ASA). Beginning in 1966, he served as secretary general of CLASC/CLAT for 34 years. Within that time, he represented a more militant, anti-imperialist and Third World orientation than the Chilean Christian Democrat leaders in charge of CLASC until then. From 1967 he also held the WCL Vice-presidency.

16. Córdova has defined CLASC's ideology as a mixture of democratic socialism and revolutionary humanism, while Wahlers has characterized this stage, opened since its seventh congress, as the "ultra-leftist phase" of the organization.

17. "Solidary development" was defined as "development at the measure of man, of the whole man and of all men." For the shift to liberation, see CLASC, Vocero del sindicalismo revolucionario en América Latina (Caracas, year III, no. 24, 1969), 2, in IISH. A similar shift, reflected in the rise of liberation theology, had occurred some years before in the Latin American Catholic Church.

18. CLAT, Vocero, year VIII, no. 64, July-August 1974, 2.

19. Daniela Spencer, ed., Espejos de la Guerra Fría: México, América Central y el Caribe (México, 2004); Hal Brands, Latin America's Cold War (Cambridge, 2010).

20. Such as CIA actions in Guatemala (1954), Bay of Pigs (1961), Brazil (1964), and the Dominican Republic (1965). Arguing the process of economic, social, and democratic progress that it would bring to Latin America, President J.F. Kennedy referred to the program as a "peaceful revolution."

21. Ian Roxborough, "La clase trabajadora urbana y el movimiento obrero en América Latina desde 1930," in Historia de América Latina, vol. 12, ed. Leslie Bethell (Barcelona, 1997), 160-75.

22. CLAT, CLAT en la encrucijada. Informe político y de orientación presentado por Emilio Máspero, secretario general de la CLAT, a nombre del Comité Ejecutivo Latinoamericano, ante el VII Congreso de la CLAT (Caracas, 1978), 65, in IISH.

23. For example, condemning the Vietnam War, US intervention in the Dominican Republic and its validation of the 1964 coup in Brazil, or the Alliance for Progress program. They also questioned bodies such as the Organization of American States for their reproduction of regional inequalities.

24. Given definitions correspond to a document written in 1977. CLAT, CLAT en la encrucijada, 181-87. By drawing on the Movement of Workers' values - inspired by Christian humanism - in the 1971 document "Strategy and Policy. CLAT VI Congress," communitarian socialism was understood as the historical synthesis of an authentic and comprehensive democracy that sought to empower workers and organized people in economic, political, social, and personal terms. The sources of inspiration on this matter were Che Guevara and the Gospel.

25. CLASC, Vocero, year IV, no. 31, 1970, 1. They explicitly stated, "CLAT rejects any techno-bureaucratic elaboration based on thinking elites, isolated on artificial ideological laboratories. The historical project of a new society will be a collective creation of all workers in their daily process of information - reflection-action." CLAT, CLAT en la encrucijada, 187.

26. Both of them were located in Caracas. ILATES started functioning in 1966. Its predecessors were the Departamento de Educación Obrera (DEO), set up in 1954-afterward named Departamento de Educación de los Trabajadores (DET) - and the Institutos Internacionales de Estudios Sociales (IIES) from the South and the Caribbean, created in 1963.

27. These were ICAES (Instituto Centroamericano de Estudios Sociales) set up in 1964 and located first in Guatemala and then in Costa Rica, covering the Central American region; INCASUR (Instituto de Capacitación Social del Sur) founded in 1970 with headquarters in Uruguay, whose activities reached the Southern Cone; the INANDES (Instituto Andino de Estudios Sociales) did likewise in the Andean region from Lima; as the INFOSCAR 
(Instituto de Formación Social del Caribe) in the Caribbean. The activities carried out by ICAES were by far superior, both in quantity and quality. For example, out of the 210 events carried out during 1975, 107 corresponded to this center, counting with 2,782 participants over a total of 5551. CLAT, Informativo CLAT. Vocero del movimiento de los trabajadores comprometidos con la liberación de los pueblos de América Latina, Caracas, year I, no. 1, 1976, 10, in IISH.

28. The Centro de Comunicación (CECUTAL), Centro de Información y Documentación (CIDUTAL), and the Departamento de Estudios e Investigaciones were established as specialized bodies to support the educational tasks.

29. CLASC, Formación de trabajadores, 151.

30. CLASC, Vocero, year I, no. 7, October 1967, 3; CLASC, Vocero, year II, no. 21, 1969, 3.

31. UTAL, Diez años, 10.

32. CLAT, Proyecto UTAL, vol. 2, Anexos: III-Resumen estadístico de los eventos realizados por el ILATES desde noviembre de 1966 a diciembre de 1972, in KADOC BE/942855/ 757/1047.

33. OIT, Educación Obrera, Ginebra, no. 1, June 1964, 7 and no. 2, 1964, 6.

34. Alexander, International Labor, 210-11. According to Francis, this expenditure represented fifty percent of its budget. Francis, "Revolutionary Labor," 603.

35. Even though CLASC/CLAT emphasized the importance of the movement financing itself, this ideal was rather difficult to achieve in practice given the scarce financial capacity of its supporters. CLASC/CLAT received funding from the Konrad Adenauer Foundation's Institute for International Solidarity (IIS) and from the Misereor Foundation (both German); also from the Chilean Fundación Alberto Hurtado; and from the IFCTU/WCL's Solidarity Fund, as well as from several European Christian trade unions. It also organized an annual campaign destined to raise funds among its rural and urban affiliates.

36. This amount corresponds to the years in which UTAL initiated its activities (19741978), taking into account costs in personnel, operational expenditures, and events (without distinguishing by type and duration). CLAT, Proyecto UTAL, vol. 3, Cuadro 2, in KADOC BE/ 942855/757/1047.

37. ILATES, Proyecto. Construcción del Instituto Latinoamericano de Estudios Sociales (ILATES) como la futura Universidad de los Trabajadores de América Latina. Código 0153-123-101(Caracas, n.d. [approximately mid-1972]), 18, in KADOC BE/942855/757/1054; UTAL, Diez años de la UTAL: Algunos aspectos evaluativos (San Antonio de los Altos, 1984), 31, in KADOC BE/942855/757/1045.

38. The writing of the book was assigned to Rodolfo Efrén Romero Garcete (former subdirector of ILATES and director of INCASUR) and was based on the findings and collective discussion of the ILATES team, comprised by José de Jesús Plana, Víctor Durán, Oscar Martínez, Acacia Máspero, Gerardo Inehausti, and others.

39. CLASC, Formación de trabajadores, 113.

40. These were oral, written, visual, and audiovisual aids. In each case the list is vast and detailed, paying much attention to the latter. In fact, the Fourth Course-Seminar for Trainers was dedicated to the use of audiovisual means in adult education. Twenty-five educators stayed more than a month in a German Confederation of Trade Unions (DGB) training school, traveling afterward to ILO headquarters in Geneva to acquire expertise in the same area. CLASC, Vocero, year II, no. 18, September 1968, 11, and no. 19, October 1968, 7.

41. Some later documents added a forth field: to know how to make someone make (teamwork and working groups).

42. Many of the concepts in this handbook can already be read in the conclusions coming from the working teams of the third course seminar held in 1967. ILATES, La formación de los trabajadores en la CLASC. III Curso-Seminario Latinoamericano para Responsables de la Formación de los Trabajadores. Conclusiones de los Trabajos de Grupo, September 4-30, 1967 , in KADOC BE/942855/757/1054. Assistants to such courses were preferably those who had participated in previous activities; in this way some sort of progression was guaranteed or expected. Forty-five educators took part in this third course held in 1967. CLASC, Vocero, year I, no. 7, October 3, 1967.

43. Ibid., 33.

44. These three stages pointed to (1) seeing the facts and situations that were part of the community or group's life; (2) judging them, which was done on the basis of Christian doctrine and Bible readings; and (3) acting individually and collectively to achieve the intended 
purposes. Cardijn's method achieved broad circulation since its inclusion in the Mater et Magistra Encyclical (1961) by Pope John XXIII.

45. While the printed course books usually lacked bibliographical references, Paulo Freire is quoted in them, and allusions to his work can be found other CLASC/CLAT publicationsfor example, in CLASC-DELAT, Los problemas de la educación en Latinoamérica, 1968, in IISH. Note that the reference is simultaneous to the publishing year of "Education as the Practice of Freedom." Between 1968 and 1970 came out "Pedagogy of the Oppressed," a text that appears among the bibliographical citations of the Guide for the Animator corresponding to the Second Cycle of the Collective Process of Ideological Elaboration (to which we will refer below). By late 1969, Pablo de Tarso, former minister of education of João Goulart, spoke about "the new procedures incorporated into Paulo Freire's literacy and conscientisation method, and its implementation for the organization of the people." CLASC, Vocero, year III, no. 27, September-October 10, 1969. We should recall that Freire carried out his educational project in Brazil during the early 1960s, being interrupted by the 1964 coup. The reading of his works was inescapable for the Christian-base communities of the time, especially among those dedicated to education. As well, the commitment to a "liberating education" appearing in the final document of the 1968 CELAM's meeting speaks about his influence. In the First Workers Conference of Education and Culture of Central America and the Caribean (Curazao, April 1974), Máspero commented on the doings of "friend Paulo Freire" in Brazil, "a man whose work all of you know for sure". CLAT, Una nueva educación en la perspectiva del Movimiento de los Trabajadores (Caracas, 1974), 9 and 8, respectively, in KADOCBE/ 942855/757/1041.

46. Pilario explicitly points out the connections among them. Daniel Pilario, Back to the Rough Grounds of Praxis: Exploring Theological Method with Pierre Bourdieu (Leuven, 2005), 536-37.

47. This can be clearly seen in the development of the PCEI, which will be described in the next section. We should recall that study circles were YCW's organizational germ, consisting of small groups who met weekly to study various issues and prepare for action, based on the "to see - to judge - to act" method. This "survey" was guided and evaluated by a priest who had to submit in turn a report to the Federation in order to create an archive that would serve to detect new problems arousing from the world of labor. Abelardo Soneira, "La Juventud Obrera Católica en la Argentina: de la secularización a la justicia social," Revista Justicia Social 5/8 (1989): 77.

48. In the sense that awareness departs from that reality (and not from something unfamiliar or distant), questions, and adds complexity to it and in such process seeks politicization and critical thinking. The entire pedagogical idea structuring the educators' manual to which we are referring; the dialectic reality-reflection-awareness raising transformative action that impregnates CLASC/CLAT's praxis; or when Máspero refers to different types of consciousness (magical, naïve, critical, political) support this assertion.

49. CLASC, Formación de trabajadores, 142-43.

50. Íbid, 248. They considered themselves as militants of the labor movement and technicians of the union organization (specialized in adult education).

51. UTAL, Compilación de las evaluaciones de los Departamentos y Centros de la UTAL. Apartado "Informe evaluativo de la sección Proceso Ideológico y Formación Abierta del Departamento de Formación" (San Antonio de los Altos, 1975), 5-6, in KADOC BE/942855/ $757 / 1045$.

52. Its combative lyrics can be read in Gabriela Scodeller, "Sources for Latin American Research at the International Institute of Social History. La CLASC/CLAT," European Review of Latin American and Caribbean Studies 98 (2015), 103.

53. CLAT, Vocero, year VII, no. 51, June 1973, 8; year VIII, no. 58-59, January-February $1974,13$.

54. Máspero's discourse in the Third Latin-American Meeting of CLAT's Trainers. CLAT, Vocero, year VI, no. 48, March 1973, 2. Bold in original.

55. The time length was of six, ten, eight, and twelve months respectively, initiating in July 1973 and finishing in July 1976.

56. CLAT, Vocero, year VII, no. 55-56, October-November 1973, 10.

57. Its relevance was such that one of the instructional brochures was entirely dedicated to the topic. See CPL, Instructivo para la realización del Círculo de Estudios. Instructivo, no. III, 
(Caracas, 1972) in KADOC BE/942855/757/1043. There were also numerous journalistic notes dedicated to explain the importance and way of functioning of these study circles.

58. CLAT, Proceso Colectivo de Elaboración Ideológica. Ciclo II: Aportes de la CLAT al movimiento de los trabajadores, "Guía para el animador," (Venezuela, n.d.), 4.

59. CLAT, Vocero, year VIII, no. 63, June 1974, 2.

60. This phase was supposed to start immediately after the VI Congress, but it was postponed until November 1971.

61. Apparently, according to the report of Ricardo Reyes (responsible for PCEI implementation at this stage), the second cycle was conducted only through these study journeys. With approximately forty participants, two subjects were analyzed throughout an entire day. INES Venezuela, "5 Tema: Proceso Colectivo de Elaboración Ideológica," Primer Seminario Nacional de Actualización Ideológica (Caracas, 1975), 7, in KADOC BE/942855/757/1043.

62. UTAL, "Informe evaluative ...," Compilación ... Apartado, 3.

63. UTAL, Compilación de las evaluaciones de los Departamentos y Centros de la UTAL, Apartado, "Elementos a considerar en la Evaluación de la Sección Campesina del Departamento de Formación de la UTAL," (San Antonio de los Altos, 1975), 44 in KADOC BE/942855/757/1045.

64. Ibid., 5 .

65. CPL, Instructivo general del Proceso de Discusión y Elaboración Ideológica. Instructivo, no.I (Caracas, 1972), in KADOC BE/942855/757/1043.

66. During this period a reorientation in CLAT's editorial policy also took place. Since April 1976 Informativo CLAT replaced the previous periodical publications. Late that year the quarterly Revista de orientación ideológica y política came out, intended as an instrument to deepen strategic and doctrinal debates.

67. CLAT, Universidad de los Trabajadores de América Latina. Estatutos, in KADOC BE/ 942855/757/1047.

68. They had to acquire basic knowledge and information regarding the subjects to be studied during the course, read certain documentation that was sent to them, and write a series of analytical reports about their national reality. UTAL, Plan de trabajo y calendario de actividades 1976 (San Antonio de los Altos, 1976), 9-10, in KADOC BE/942855/757/1045.

69. UTAL, Diez años, 11-16.

70. CLAT, CLAT en la encrucijada, 106-19.

71. In this respect they defined that CLAT had become "a class organization of masses and of confrontation." This brought about new demands in matters of leadership; ideological, political, and strategic orientation; as well as operational and practical ones. CLAT, Sólo el poder, 178.

72. The dispute was with the Marxist-Leninist left, of which CLAT criticized its political strategies and the way they intervened in the labor movement.

73. CLAT, CLAT en la encrucijada, 107.

74. CLAT, Sólo el poder, 242 and 240, respectively.

75. Ibid., 193-94.

76. Ibid., 214.

77. ILATES, La formación de los trabajadores.

78. UTAL, "Elementos a considerer ...," Compilación ... Apartado, 42.

79. Half the assistants to this 1975 seminar (I Seminario de Formación Global para Cuadros de Conducción Política y Estratégica) had gone through university, while the rest had completed studies at a secondary level. UTAL, "Evaluación de la sección Eventos de Larga Duración del Departamento de Formación de la UTAL," Compilación de las evaluaciones de los Departamentos y Centros de la UTAL. Apartado, San Antonio de los Altos, November 1975, 1-14, in KADOC BE/942855/757/1045.

80. UTAL, Circular 013/79. Asunto: Programa de Formación de Formadores. Proyecto: Programa de Formación de Formadores, I Parte (San Antonio de los Altos, 1979), 1-2, in KADOC BE/942855/757/340. 